\title{
Severe anaemic retinopathy in primitive neuroectodermal tumour
}

\author{
Abhilasha Arvind Alone, Komal Agarwal
}

Vitreo-Retina, Smt. Kanuri Santhamma Retina Vitreous Centre, LV Prasad Eye Institute, Hyderabad, Telangana, India

\section{Correspondence to} Dr Komal Agarwal, komal.agarwal.vr@gmail.com

Accepted 23 July 2019

\section{DESCRIPTION}

A 9-year-old girl presented with chief complaints of sudden painless diminution of vision in both eyes 6 days ago. Her visual acuity was PL + PR accurate in the right eye and counting fingers in the left eye. She was a known case of spinal extradural primitive neuroectodermal tumour since 2016. She had undergone chemotherapy, laminectomy and excision of the tumour in May 2016 and radiotherapy in August 2017. At presentation, she had metastases in bones and lungs and was on chemotherapy. There was a history of recent drop in haemoglobin to $22 \mathrm{~g} / \mathrm{L}$ for which she received blood transfusions. Both eyes showed haemorrhages at multiple levels-preretinal, intraretinal, subhyaloid and vitreous (figure 1A,B). Her current haemoglobin was $105 \mathrm{~g} / \mathrm{L}$ and peripheral blood smear showed thrombocytopenia with small clumps and normocytic normochromic anaemia with anisocytosis. Ocular features were likely due to pancytopenia secondary to myelosuppression. She was called for follow-up after stabilisation of her systemic condition but she did not turn up for follow-up. Three months later, we found that she had succumbed to systemic complications due to metastases.

Anaemia causes retinopathy in $28 \%$ of patients, especially when it is also associated with thrombocytopenia (38\%). As the severity of anaemia increases, the risk of retinopathy increases, particularly when

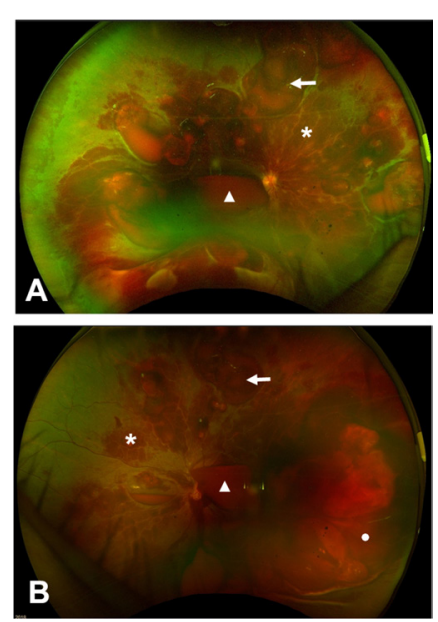

(C) BMJ Publishing Group Limited 2019. No commercial re-use. See rights and permissions. Published by BMJ.

\footnotetext{
To cite: Alone $A A$, Agarwal K. BMJ Case Rep 2019;12:e230365. doi:10.1136/bcr-2019230365
}

Figure 1 (A) Wide field colour fundus photo of the right eye showing multiple preretinal (arrow) subhyaloid (triangle) and intraretinal haemorrhages (asterisk). (B) Wide field colour fundus photo of the left eye showing multiple preretinal (arrow) subhyaloid (triangle), intraretinal haemorrages (asterisk) and vitreous the haemoglobin level is below $60 \mathrm{~g} / \mathrm{L} .^{1}$ Thrombocytopenia associated with anaemia leads to defective coagulation and haemorrhages. Other factors suggested in the pathology are venous stasis, angiospasm, increased blood viscosity (myeloproliferative disorders), hypotension (following haemorrhage) and so on. Hypotension may lead to optic neuropathy. ${ }^{2}{ }^{3}$ Haemorrhages at multiple levels in the fundus are seen in anaemia especially when thrombocytopenia coexists in diseases like aplastic anaemia, leukemias, autoimmune diseases and in those with infectious endocarditis. ${ }^{2}$ Therefore, blood investigations should include peripheral blood smear examination in addition to complete blood picture. Bone marrow biopsy may be helpful in some cases where diagnosis of the primary condition is not known yet. Vision typically improves in 1-2 months with self-resolution of haemorrhage and improvement of haemoglobin and platelet levels after treatment of the primary disease.

\section{Learning points}

As the severity of anaemia increases, the risk of retinopathy increases, especially when there is associated thrombocytopenia.

- Subhyaloid haemorrhage and vitreous haemorrhage though rare can be seen in severe anaemic retinopathy.

- Peripheral blood smear should be included in complete blood workup to rule out any underlying malignancies.

Contributors AAA drafted the article and revised it critically for important intellectual content. KA contributed to the final approval of the version to be published. Both authors contributed to the conception and design, acquisition of data or analysis and interpretation of data and agreed to be accountable for the article and to ensure that all questions regarding the accuracy or integrity of the article are investigated and resolved.

Funding The authors have not declared a specific grant for this research from any funding agency in the public, commercial or not-for-profit sectors.

Competing interests None declared.

Patient consent for publication Obtained.

Provenance and peer review Not commissioned; externally peer reviewed. haemorrhage (dot). 
Copyright 2019 BMJ Publishing Group. All rights reserved. For permission to reuse any of this content visit https://www.bmj.com/company/products-services/rights-and-licensing/permissions/

BMJ Case Report Fellows may re-use this article for personal use and teaching without any further permission.

Become a Fellow of BMJ Case Reports today and you can:

- Submit as many cases as you like

- Enjoy fast sympathetic peer review and rapid publication of accepted articles

Access all the published articles

Re-use any of the published material for personal use and teaching without further permission

Customer Service

If you have any further queries about your subscription, please contact our customer services team on +44 (0) 2071111105 or via email at support@bmj.com.

Visit casereports.bmj.com for more articles like this and to become a Fellow 